УАК 323(470+571)

ББК 66.3(2Poc)

DOI 10.22394/1682-2358-2019-4-89-98

V.V. Vlasov, Candidate of Sciences (Politics), Docent of the Social and Philosophical Disciplines Department, Lukyanov Orel Law Institute of the Ministry of the Iterior of Russia

O.S. Gorodina, Candidate of Sciences (Politics), Docent of the General and Applied Political Science Department, Orel State University named after I.S. Turgenev

\section{THE ROLE \\ OF TRADITIONAL RELIGIONS \\ IN THE SOCIAL \\ AND POLITICAL LIFE OF MODERN RUSSIA}

The significance of traditional religions in the social and political life of Russia is considered. Special attention is paid to the definition of promising areas of interaction between traditional religious denominations and public authorities in addressing social problems.

Key words and word-combinations: traditional religions, state-confessional relations, modernization of Russia.
B.В. Власов, кандидат политических наук, доцент кафедрь сочиально-философских дисчиплин Орловского юридического института МВА России имени В.В. Аукьянова (email: vitaliyy_ vlasov@ro.ru)

О.С. Городнина, кандидат похитических наук, дочент кафедрь общей и прикладной политологии Орловского государственного универcuтета имени И.С. ТургенеВа (email: ogorodnin@@ yandex.ru)

\section{РОАЬ ТРААИЦИОННЫХ РЕАИГИЙ В ОБЩЕСТВЕННО- ПОАИТИЧЕСКОЙ ЖКИЗНИ СОВРЕМЕННОЙ РОССИИ}

Аннотация. Рассматривается значение традиционных религий в общественно-политической жизни России. Особое внимание уделяется выявлению перспективных направлений взаимодействия традиционных религиозных конфессий с органами государственной власти в решении общественно значимых проблем.

Ключевые слова и словосочетания: традиционные религии, государственно-конфессиональные отношения, модернизация России.

P вахкную роль в Аизни полняя коммуникативную, интегративную, 
регулятивную, психотерапевтическую функции, а также использовалась Аля обеспечения стабимьности Аействующей власти. Как отмечам М. Вебер, «...peмигиозность политических субъектов способна придавать им особые харизматические качества, обладающие наибольшей мегитимирующей симой...» [1, с. 122]. ОАнако начиная со второй половины XVIII в. наблюдался процесс уменьшения авторитета Церкви и ее служителей в общественно-политической жизни большинства европейских государств, что отражено в трудах многих выдающихся философов того периода. В частности, Ж.-Ж. Руссо писал: «... человек вынужден иногда кривить душой, если он епископ» [2, с. 54]. Это позволило многим мыслителям говорить о необратимости Аанного процесса и даже постепенного исчезновения религии, как это объяснялось в учении К. Маркса. Указанные прогнозы не подтвердились; начиная со второй половины XX в. отмечается «...глобальное возрождение религии» [3, с. 137]. Не стала исключением и Россия, где после десятилетий господства атеизма произошел настоящий религиозный ренессанс: «В 1994 году 30\% россиян в возрасте 25 мет сказали, что они перекцючицись с атеизма на веру в Бога» [3, с. 139] .

Религиозное возрождение в России происходияо на фоне перехода от тоталитарного политического режима к демократическому; как следствие, наступиц «...идеологический кризис, последовавший за отказом от коммунистической идеологии» [4, с. 25]. Ауховный вакуум был заполнен культом Аенег, насилия, порнографии и другими аморальными явлениями. Таким образом, история 1990-х годов демонстрирует, что невозможно в оАночасье установить Аемократию в обществе, которое на протяжении столетий находицось в рамках авторитарного и тоталитарного политических режимов. По мнению выдающегося русского мыслитемя И.А. Ильина, «демократия имеет свои жизненные основы - в духе народа, его правосознании, его соџиальном укмаде. Нет этих основ, и демократия выродится - или в охлократию..., или в тиранию» [5, с. 154]; С.Н. Булгаков утверждал, что «демократические трансформации Аолжны быть в согласии с православными ценностями» [6, с. 37]. Следовательно, в контексте модернизации российского общества особую актуальность приобретает проблема взаимоотношений государства с религиозными объединениями [7, с. 139].

Опыт реформирования некоторых восточных стран, например, Японии и Китая, подтверАиц, что эффективное развитие невозможно без опоры на траАиционные ценности. Поэтому Аля современной России важно учитывать ценности как православия, так и других традиционных религий, а также будАизма и иудаизма. «При рассмотрении путей обеспечения стабильности современной России необходимо объективное понимание роли исламских организаций во внутриполитических процессах государства...» [8, с.102]. Это обусловило необходимость выстраивания с ними отношений социального партнерства, которое представмяет собой «...систему взаимодействий органов государственной вцасти и органов местного самоуправцения с религиозными организаџиями, направленную на обеспечение реализации последними уставных целей и заАач в решении соџиально значимых проблем» [9, с. 105]. Как следствие, к середине 1990-х годов сложилась коопераџионная модель государственно- 
конфессиональных отношений, предполагавшая приоритетное сотрудничество государственных органов с наиболее массовыми и влиятельными религиозными объединениями во всех сферах жизни общества [7, с. 146] .

Важным шагом стало принятие 26 сентября 1997 г. Федерального закона № 125-Ф3 «О свободе совести и религиозных объединениях», которым закреплялась особая роль православия для России, становления ее духовности и культуры. Кроме того, было зафиксировано уважение к христианству, исламу, буддизму, иудаизму и Аругим религиям, составляющим неотъемлемую часть исторического наследия народов России, так как за продолжительный исторический период функционирования на российской территории их ценностные установки стали неотделимы от культуры. Таким образом, страна пошла по пути ряда демократических европейских государств, которые, гарантируя право на свободу совести, в то же время закрепили особый правовой статус «исторических конфессий». Соответственно, невозможно поддерживать культурно-просветительские и иные проекты, не оказывая помощи крупным религиозным объединениям:

1) православному христианству, широко распространенному в Российской Федерации;

2) суннитскому течению ислама, мокализованному в районах Поволжья и Северного Кавказа: ханафитский мазхаб в Повомжье; шафиитский на Северном Кавказе (в основном в виде различных суфийских вирдов);

3) будАизму школы Гэлуг в Каммыкии, Тыве, Бурятии;

4) иудаизму - наџиональной религии еврейского народа, особенно его ортодоксальной форме и хасидизму.

Традиционные конфессии получают помощь от государства в строительстве объектов культа, а духовные миџа приглашаются для проведения различного рода официальных мероприятий. РПЦ и Аругими религиозными организациями приняты основы соџиальных конџепџий, где обозначен их взгляА на основные проблемы современного российского общества; при этом, как отметил Патриарх Киримл: «... никакая сфера жизни общества намеренно или искусственно не должна быть закрыта для взаимодействия с Церковью» [10, c. 280] , поэтому спектр проблем, решаемых органами вцасти с привлечением традиционных религиозных конфессий, весьма широк.

На государственном уровне признано, что основной проблемой русского народа явмяется демография. С 1990-х годов наблюдается проџесс депопуляции русского и некоторых других коренных народов России. Аюдские потери в значительной степени удалось компенсировать благодаря миграции русского и русскоязычного населения из бывших союзных республик. После ряАа мер, преАпринятых руководством страны (материнский капитал, пропаганда престижности семьи с несколькими детьми и т.А.), а также вступления в фертильный возраст многочисленного поколения 1980-х годов, в 2000-х годах удаАось несколько улучшить ситуацию. ОАнако благоприятный период заканчивается, а на смену многочисленному поколению 1980-х приходит поколение 1990-х годов, малочисленность которого обусловлена переходным периодом этого времени. От преодоления данного кризиса зависит будущее российского народа, а также сохранение современных границ России. 
По мнению П.Аж. Бьюкенена, при сохранении негативных тенденщий в сфере демографии, «... к 2050 году Россия потеряет значительную часть Сибири и будет вынуждена уйти с Кавказа» [11, с. 150]. Прогноз П. Аж. Бьюкенена в отношении России слишком пессимистичен, однако сложившаяся ситуация требует от общества серьезных усилий и использования всех имеющихся среАств. Религиозный фактор будет иметь существенное значение, так как оАной из основных причин демографического кризиса явмяется «коммапс морали и ремигии» $[11$, с. 69].

Связь межАу религиозностью и желаемым количеством детей прослеживамась на протяжении истории. Так, в Аревнем Риме периода упадка демографические взгляды христиан (не допускавших аборты и берущих на воспитание чужих детей) разительно отличались от поведения язычников. В настоящее время, посешая Аюбой городской православный храм ияи баптистский момельный дом в течение месяџа, можно заметить, что практически в каждом приходе имеются многодетные семьи.

Филофей Псковский сформулировал основные положения знаменитой теории «Москва - третий Рим», однако применительно к современной России возникает вопрос: это Рим периода подтема, где наџиональная религия пользуется уважением граждан и в приоритете крепкая семья, или упадка, требующий «хмеба и зрелищ». На справеАливость последнего тезиса указывает тревожная тенденџия: «... фактическое количество прерванных беременностей может превышать 1 млн в гоА, в то время как число родившихся в России в 2016 г. составляло 1893,3 тыс. человек» [12, с. 26]. Максимальное количество абортов было зарегистрировано в 1960-е годы и их стабильное снижение отмечалось Аишь с конца 1980-х годов, поэтому сегодняшние цифры не являются абсолютными. Общая цифра за указанный период приближается к десяткам мимлионов человеческих жизней, из чего следует вывоА, что нароА совершает Аобровольное самоубийство.

Запрет на производство абортов, существовавший в сталинские времена, Аал кратковременный эффект, его стали обходить или делать нелегально. Поэтому решение вопроса представцяется не в запрете абортов (хотя, учитывая наличие современных средств контраџепџии, государство должно прекратить их финансирование за счет налогоплательщиков, кроме случаев, связанных с изнасилованием), а в том, чтобы изменить отношение общества к данному явлению. Аیя этого необходимо принять позиџию традиџионных религиозных конфессий, которые утвержАают, что аборт - это не просто медищинская операция, а убийство неродившегося ребенка. Родителям, желающим сделать аборт, следует предоставмять возможность побеседовать с преАставителем ремигиозной конфессии, к которой они себя относят, чтобы убедить сохранить ребенку жизнь.

Большую роль в снижении рождаемости, помимо объективных факторов (высокий темп жизни в городе, вовлечение женщины в производственные отношения, увеличение расходов на содержание и обучение детей и т.А.), играют факторы субъективные, обусловленные «раџиональным эгоизмом». Суть данного явления заключается в том, что потенциальные родители, даже имея 
необходимые средства, уклоняются от рождения детей, мибо рожают максимум одного ребенка "ААя себя». Исходя из эгоистических соображений это оправдано, так как жертвовать средствами, комфортом и работой придется сейчас, а старость часто проще обеспечить самим. Более того, чем выше доход имеет женщина, тем сложнее семье решиться на первого и последующих детей. Невозможно кардинальным образом решить демографический вопрос исключительно материальными средствами, но на урегулирование этой проблемы может существенно повлиять идеологическая установка граждан. Соответственно, позиция традиционных религиозных конфессий, призывающих к ограничению потребительского эгоизма и созданию крепких многодетных семей, представляется своевременной и ее необходимо поддерживать на госуАарственном уровне, а дмя этого следует использовать не только возможности приходов и церковных средств массовой информации, но и государственного телевидения.

Тесно связанной с демографией является проблема зАравоохранения и особенно потребления алкоголя и наркотических средств. Государство прилагает серьезные усилия дмя борьбы с этим явлением и использование религиозного потенциала также может стать эффективным среАством снижения остроты Аанной проблемы: традиционные конфессии запрещают употребление наркотических средств и психотропных вешеств и негативно относятся к чрезмерному употреблению алкоголя (в исламе запрешен и алкоголь).

В настоящее время многие религиозные организации проводят реабицитацию мюдей, больных алкоголизмом и наркоманией. Так, «...с середины 1990-х годов количество православных реабилитационных центров увеличилось Ао 40» [13, с. 76]. В них установлен строгий распорядок Аня, наполненный трудом и молитвой. Часть пациентов остаются после курса реабилитаџии в центрах для оказания помощи другим больным. Кроме того, значительное внимание уделяется исцелению не только тела, но и души, то есть устраняются не только следствия, но и причины, вызывавшие пагубную привычку. Больному предлагается альтернатива Аля Аальнейшей жизни.

Аемографический кризис обусловливает необходимость привлечения в Россию мигрантов, так как обеспечение экономического роста и выполнение социальных обязательств невозможно без дополнительных рабочих рук. Более того, в случае существенного уменьшения населения интерес к России как к рынку сбыта будет снижаться, поэтому в условиях отдаленной перспективы резкого увеличения рожАаемости миграция явмяется важным фактором компенсации демографических потерь. Опыт стран Западной Европы свидетельствует о том, что политика мультикультурализма себя не оправдала, так как значительная часть мигрантов не пожелали ассимилироваться в принимающем обществе. Они создают этнические и религиозные анклавы, где нередко навязывают свои правила коренному населению, что необходимо учитывать при выстраивании национальной демографической помитики.

В Россию в основном приезжают гражАане бывших советских респубцик, в первую очередь Украины и республик Центральной Азии. Украинские мигранты, близки в культурном и религиозном плане к русскому народу и доста- 
точно мегко ассимилируются в российском обществе. В связи с этим решение Президента РФ В.В. Путина об упрошенной проџеАуре предоставления гражданства дия жителей отдельных районов Ауганской и Аонеџкой областей представцяется своевременным. Более того, по нашему мнению, мьготные условия предоставления российского гражданства следует распространить на всех граждан Украины и Белоруссии, а также соотечественников, проживающих за рубежом. РПЦ, располагая довольно разветвленной сетью приходов, можкет играть существенную роль в их возвращении на родину и адаптации на новом месте жительства.

Иная ситуация с мигрантами из Центральной Азии. В 1990-е годы большинство желающих остаться жить на территории России составцяли русские

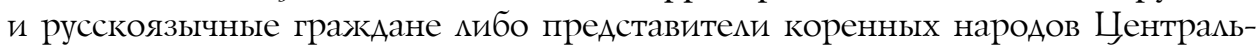
ной Азии, выросшие в СССР, хорошо знавшие русскую культуру и являвшиеся ее носителями. В настоящее время обстоятельства изменились, так как значительная часть мигрантов из данного региона - это мюАи, слабо вцадеющие русским языком и не считающие русскую культуру своей. В государствах Центральной Азии за время независимости произошио рекигиозное возрожкение в рамках исламской религии, в том числе ее радикальных течений, при этом Аля будущего места жительства и работы мигранты часто выбирают "русские» регионы, где традиционно доминировало православное христианство. В связи с этим целесообразно изучать суть «...соџиальных явлений и проџессов, происходящих в обществе, где традиџионно исповедуется ислам и христианство, представители которых диительное время существуют совместно» [14, с. 6], как в Повоцжье. Кроме того, следует предоставить всем традиционным конфессиям максимальные возможности Аля миссионерской деятельности среАи мигрантов. Речь не идет о навязывании религии, а только о создании условий, позволяющих ознакомиться с культурой страны пребывания. В качестве положительного примера, можно привести реализуюшуюся в Москве «Программу 200»: Аанный проект предполагает строительство минимум одного храма на каждые 20 тыс. жкителей при пешеходной Аоступности около оАного километра; муниципальные власти выделяют только землю, а строительство осуществцяется за счет пожертвований.

Проблема миграции неотделима от вопроса обеспечения межнациональной и межконфессиональной стабильности. В этом аспекте у России имеется существенное преимущество перед западными странами; исторически она развивалась как многонаџиональное и многоконфессиональное государство и имеет большой опыт в обеспечении межкнационального и межкконфессионального мира и согласия межАу преАставителями разАичных этнических и религиозных групп. ПреАставители традиџионных религиозных конфессий выработали уникальный механизм взаимодействия: проповедуя свои идеи, не унижать и не оскорбцять иные религиозные убеждения, избегая при этом агрессивного прозелитизма.

В то же время события в некоторых арабских странах и на Украине показали, что межрелигиозные и межнациональные разногласия могут использоваться внешними силами для подрыва неугодных им политических режимов,

94 Bulletin of the Volga Region Institute of Administration • 2019. Vol. 19. № 4 
поэтому необходимо предпринимать максимум усилий Амя борьбы с угрозами, направленными на дестабилизацию политической обстановки в стране по мотивам национальной или религиозной ненависти или вражды. О тех, кто провоцирует межжэтническое напряжение в России, Президент России В.В. Путин заявил: «Это своего рода аморальный интернационац, в который входят и распоясавшиеся обнаглевшие выходцы из некоторых южных регионов России, и продажные сотрудники правоохранительных органов, которые крышуют этническую мафию, и так называемые русские националисты, разного рода сепаратисты» [15, с. 82].

Особую опасность представцяют нетрадиционные религиозные объединения, носящие экстремистский характер. В первую очередь это относится к разцичным течениям радикального ислама, получившим обобщенное название «ваххабизм». Возникнув на территории Аравийского полуострова, в условиях доминирования мусульманского населения, он не адаптирован к жизни в многонациональном и многоконфессиональном государстве, не учитывает особенностей национальной культуры народов Российской Федерации. Призывая к так называемому «чистому исламу» и отказу от «нововведений», ваххабизм де-факто отрицает культурные особенности других народов, предиагая всеобщую арабизацию. Это вызвало противодействие традиционных мусульманских конфессий, существующих на территории Поволжья и Северного Кавказа, а на Северном Кавказе явицось одной из причин, вызвавших гражданский конфликт.

В настоящее время представители традиционного ислама ведут активную идеологическую борьбу против радикалов. Интересен опыт Чеченской Республики, где на телеканале «Грозный» значительная часть эфира вылелена Аля ознакомления с основами суфийского течения ислама и проводится разъяснительная работа об опасности религиозного экстремизма. Активную позицию занимают представители традиционного ислама в других регионах России и, к сожалению, имеются настоящие мученики, пострадавшие за свои убеждения. Так, огромной утратой стало убийство 19 июля 2012 г. заместителя муфтия Ауховного управления мусульман Республики Татарстан В. Якупова, занимавшего активную антиваххабитскую позицию.

При профицактике экстремизма следует учитывать, что значительную часть экстремистов составцяют молодые цюАи. Молодежки всегда присущи обостренное чувство соџиальной справедливости и радикальное видение решения имеющихся проблем, что эффективно используется религиозными экстремистами; именно поэтому перед традиционными конфессиями стоит задача подготовить ярких проповедников, ориентированных на молодежный сегмент российского общества, которые, не изменяя своему вероучению в угоду времени, смогут Аонести идеи мира и Аобра, заложенные в культуре народов России. Это относится ко всем традиционным конфессиям, так как радикалы пополняют свои ряды не только выходџами из мусульманской уммы.

Oсобое внимание следует удецять экстремистам, отбывающим наказание

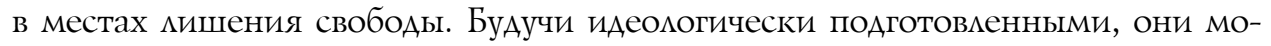
гут эффективно воздействовать на своих сокамерников. В Интернете имеется информация о тюремных Ажамаатах, когда заключенные группируются 
по религиозному признаку. Религия является важным средством воспитания законопослушного поведения, но следует учитывать возможность распространения радикальных форм вероучения. Целесообразно развивать взаимодействие учреждений пенитенциарной системы с традиционными конфессиями,

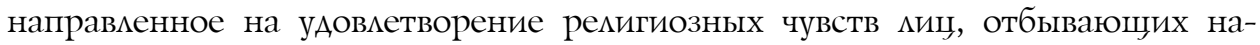
казание; кроме того, соблюдая религиозные права заключенных, необходимо изолировать экстремистов.

Важным направлением деятельности традиционных конфессий является Ауховно-нравственная и воспитательная работа с военнослужащими Вооруженных сил РФ и сотрудниками правоохранительных органов. Эта деятельность в армии осуществяется в соответствии с требованиями ФеАерального закона Российской Федерации от 27 мая 1998 г. № 76-Ф3 «О статусе военнослужащих», в ст. 8 которого закреплено конститущионное право на свободу совести и вероисповедания. По нашему мнению, по достоинству оџенен высокий потенциал религии в духовно-нравственной и воспитательной работе, так как в настоящее время просматривается тенденџия развития взаимодействия Вооружкенных сил РФ с традиционными религиозными конфессиями.

В ч. 1 ст. 8 Закона «О статусе военнослужащих» указано, что в свободное от несения службы время военнослужащие вправе принимать участие в ремигиозных церемониях как частные мица, однако на практике участие священнослужителей в проведении воинских ритуалов стало распространенным явлением. Проводятся различные религиозные обряды: например, военнослужащих благословцяют, окропляют святой водой и т.А. В то же время участие в элементах ритуала затрагивающих религиозные чувства не является обязательным, следовательно, не происходит ушемления права на «свободу совести».

В рассматриваемом Законе не Аопускается возможность отказа от исполнения служебных обязанностей по религиозным мотивам, однако с 1980-х годов в советской, а затем и в российской армии широкое распространение получили неуставные взаимоотношения, основанные не на сроке службы (деАовщина), а на региональном происхождении военнослужащих срочной службы (землянщина). Призывники из некоторых регионов страны, обладая высокой степенью организованности, будучи хорошо морацьно и физически поАготовлены, попав в расположение воинской части даже в небольшом количестве, подчиняют себе остальной цичный состав, отказываясь выполнять определенные виды работ, ссылаясь на то, что это запрещено их религией. Представляется, что нахождение на территории воинской части представитемя духовенства, который сможет аргументировано объяснить, что недопустимо укАоняться от исполнения воинского Аолга, будет способствовать укрепиению Аисџиплины. Если не менее $10 \%$ военнослужащих, находящихся на территории воинской части, декларируют принадлежность к определенной конфессии, то желательна та или иная форма участия духовного миџа в воспитательной работе, причем священнослужитель Аолжен помогать командиру, а не подменять его. Соответственно, актуальным явцяется вопрос о специальной подготовке военного Ауховенства со знанием специфики воинской службы.

В условиях непростой экономической ситуации, сложившейся в настоящее 
время, религиозные организации могли бы оказывать существенную помощь в реализаџии различных соџиальных и благотворительных программ. Это не только организация непосредственной помощи нуждающимся, но и разъяснения верующим о недопустимости поведения, направленного на обман; воровства у своих братьев; того, что не мюбая жертва угодна Богу. Это касается и такого угрожающего безопасности государства явления как коррупџия, которая с религиозной точки зрения есть не что иное, как кража.

Традиционно религия играла важную роль не только во внутриполитических процессах, но и в межгосударственных отношениях. Религиозные организации занимают особое положение в числе неправительственных участников международных отношений, деятельность которых «...может быть отнесена именно к сфере “мягкой симы” демонстрировали значение религиозного фактора в подАержании духовного единства народов России и Украины, в связи с чем важным преАставцяется оказание содействия РПЦ в деле подАержания единства «русского мира» не только на постсоветском пространстве, но и в Аальнем зарубежье, где православие играет важную роль в консолидации и обеспечении Ауховной связи русской диаспоры с родиной. Традиџионные исламские, будАийские и иудаистские организаџии также содействуют подАержанию Аиалога со странами, принадлежкащими к указанным цивилизациям. Так, в феврале 2019 г. глава Чеченской Республики Р.А. Кадыров встретился с наследным принцем Саудовской Аравии Мухаммедом бен Зайдом. То, что интересы России в одном из влиятельных мусульманских государств преАставцял руководитель исламского региона, где недавно шли боевые Аействия, сигнализирует об уважении, которое оказывается этой религии.

В последние десятияетия Россия заявияа о себе как о государстве, отстаивающем консервативные ценности, которые во многом совпадают с ценностями христианства, ислама, буддизма и иудаизма [17]. Традиџионные конфессии проводят в этом направцении значительную работу на межАународной арене. Так, РПЦ осуществляется активный диалог с «... христианскими конфессиями и организациями, а также с представителями ислама, иудаизма и будАизма по вопросам сохранения нравственности в современном мире [18, с. 15]. Важным событием стала встреча Патриарха Киримла и Папы Римского Франциска 12 апреля 2016 г. в здании международного аэропорта в Гаване, где быма сформулирована общая позищия по многим вопросам современного мира. Развивается диалог и с исламским миром: с 2005 г. Россия является наблюАателем в организации исламского сотрудничества, тем самым обозначив, что она явцяется не только кцючевым государством православного мира, но и частью исламского. Аружкественные отношения с государством Израиль в значительной степени являются следствием активной работы еврейских религиозных организаций. Большую роль в развитии связей со странами Южной, Юго-Восточной и Восточной Азии могут сыграть будАийские организации.

Итак, отметим, что традиџионные религии играют важную роль в общественно-политической жизни современной России и их вцияние продолжает расти. В Российской Федерации сложкилась кооперационная модель государс- 
твенно-конфессиональных отношений, когда государственные органы на взаимной основе подАерживают наиболее массовые и влиятельные религиозные объединения. Наиболее актуацьными проблемами, в решении которых следует использовать потенџиал традиџионных конфессий, являются вопросы демографии; соџиализаџии мигрантов; противодействия экстремизму; исправления осужденных; патриотической и воспитательной работы в вооруженных силах и правоохранительных органах; фактора «мягкой силы» в межгосударственных отношениях.

\section{Библиографический список}

1. Вебер М. Протестантская этика и дух капитализма. М., 1990.

2. Руссо Ж.-Ж. Исповедь / пер. с фр. Д.А. Горбова, М.Н. Розанова. М., 2018.

3. Хантингтон С. Столкновение цивилизаций / пер. с англ. Т. Велимеева. М., 2017.

4. Дорогин Ю.В., Кушенко И.А., Мезинова Г.Н. Русская Православная Церковь в современном российском обществе: институциональный статус и перспективы развития // Гуманитарные, социально-экономические и общественные науки. 2018. № 1.

5. Ильин И.А. О противлении злу силою. М., 2017.

6. Сабаев Е.Г. Роль Русской Православной Церкви в становлении гражданского общества в России // Известия Саратовского университета. Сер.: Социология. Политология. 2011. Т. 11, вып. 3.

7. Исаев А.В. Роль и место Русской Православной Церкви в развитии государства: история и современность // Среднерусский вестник общественных наук. 2010. № 1.

8. Вагапова Ф.Г., Вагапов Р.Н. Взаимодействие исламских организаций и государства в Российской Федерации: пути обеспечения общественно-политической стабильности // Ислам в современном мире. 2015. Т. 11, № 2 .

9. Исаев А.В. Социально-политическое партнерство органов государственной власти и Русской Православной Церкви в современной России: проблемы и пути оптимизации // Среднерусский вестник общественных наук. 2011. № 1.

10. Безбородов М.И. Основные принципы церковно-государственных отношений в социально-политической доктрине Русской Православной Церкви // Политэкс. 2010. Т. 6, № 2.

11. Бьюкенен П.Дж. Смерть Запада / пер. с англ. А. Башкирова. М., 2004.

12. Дорогин Ю.В., Кушенко И.А., Мезинова Г.Н. Русская Православная Церковь в современном российском обществе: институциональный статус и перспективы развития // Гуманитарные, социально-экономические и общественные науки. 2018. № 1.

13. Морозов E.M. Роль Русской Православной Церкви в социокультурном преобразовании Российской Федерации // Вестник Томского государственного университета. 2016. № 3 (23).

14. Мавляутдинов И.С. Социальная роль ислама как фактора стабилизации общества (на примере Республики Татарстан): автореф. дис. ... канд. социол. наук. Казань, 2007.

15. Рудакова E.К. Эволюция традиционного ислама в рамках проблемы конфессиональной безопасности Приволжского федерального округа России // Власть. 2014. № 8.

16. Касаткин П.И. Русская православная церковь как актор современной мировой политики // Вестник МГИМО. 2010. № 6.

17. Кузьменков В.А. О роли термина «контингентность» в аксиологии // Научный вестник Орловского юридического института МВД России имени В.В. Лукьянова. 2018. № 1. С. 49-51.

18. Безбородов М.И. Русская православная церковь и государство: проблемы взаимодействия и приоритеты // Вестник Волгоградского государственного университета. Сер.: История. 2009. № 1 (15). 